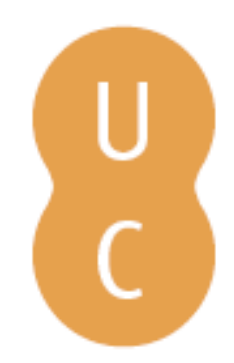

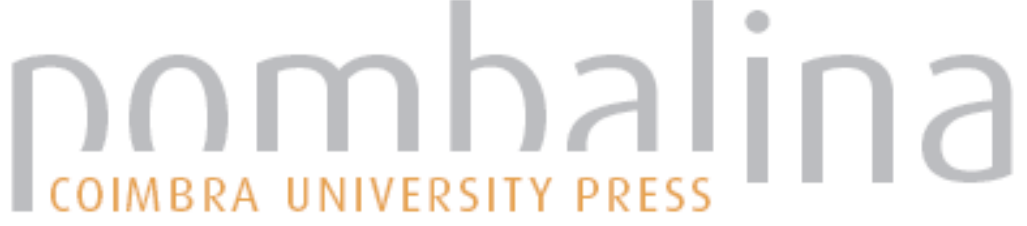

\section{Basic principles of growth and maturation}

\author{
Autor(es): Malina, Robert M
}

Publicado por: Imprensa da Universidade de Coimbra

URL

persistente: URI:http://hdl.handle.net/10316.2/31691

DOI: $\quad$ DOI:http://dx.doi.org/10.14195/978-989-26-0506-7_1

Accessed : $\quad$ 26-Apr-2023 11:47:05

A navegação consulta e descarregamento dos títulos inseridos nas Bibliotecas Digitais UC Digitalis, UC Pombalina e UC Impactum, pressupõem a aceitação plena e sem reservas dos Termos e Condições de Uso destas Bibliotecas Digitais, disponíveis em https://digitalis.uc.pt/pt-pt/termos.

Conforme exposto nos referidos Termos e Condições de Uso, o descarregamento de títulos de acesso restrito requer uma licença válida de autorização devendo o utilizador aceder ao(s) documento(s) a partir de um endereço de IP da instituição detentora da supramencionada licença.

Ao utilizador é apenas permitido o descarregamento para uso pessoal, pelo que o emprego do(s) título(s) descarregado(s) para outro fim, designadamente comercial, carece de autorização do respetivo autor ou editor da obra.

Na medida em que todas as obras da UC Digitalis se encontram protegidas pelo Código do Direito de Autor e Direitos Conexos e demais legislação aplicável, toda a cópia, parcial ou total, deste documento, nos casos em que é legalmente admitida, deverá conter ou fazer-se acompanhar por este aviso.

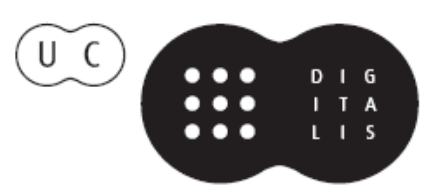


Manuel J. Coelho e Silva António J. Figueiredo Marije T. Elferink-Gemser Robert M. Malina Editors
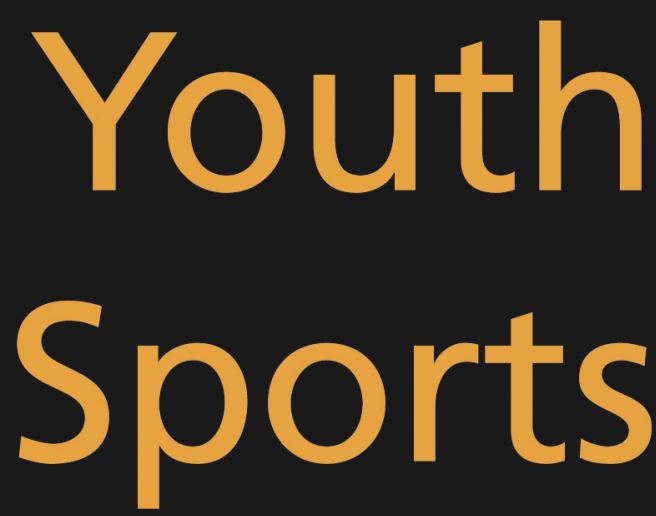

\section{Growth, Maturation and Talent}




\title{
EDIC̣̃̃o
}

Imprensa da Universidade de Coimbra

Email: imprensauc@ci.uc.pt

URL: http://www.uc.pt/imprensa_uc

Vendas online: http://www.livrariadaimprensa.com

\section{CONCEPÇÃO GRÁFICA}

António Barros

\section{EXECUÇÃO GRÁFICA}

\author{
Norprint
}

ISBN

978-989-26-0005-5

\section{DEPÓSITO LEGAL}


Manuel J. Coelho e Silva António J. Figueiredo Marije T. Elferink-Gemser

Robert M. Malina

Editors
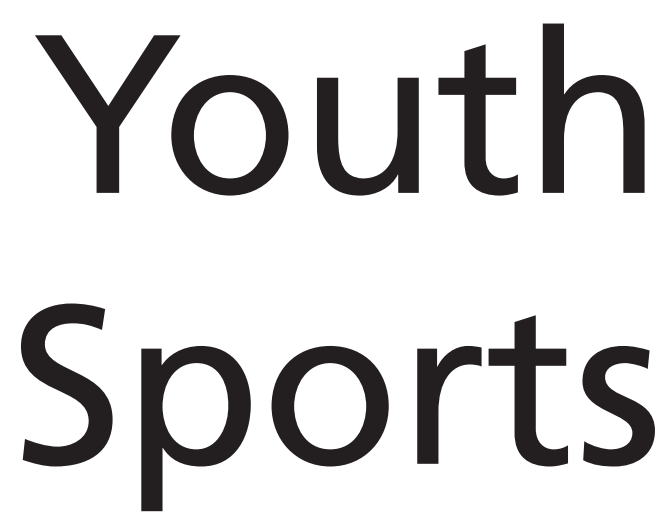

Growth, Maturation and Talent

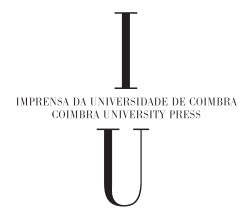


Part I:

GROWTH AND MATURATION 


\section{CHAPTER I: BASIC PRINCIPLES OF GROWTH AND MATURATION}

Robert M Malina

\section{INTRODUCTION}

The interval between birth and adulthood is commonly divided into age periods. The first year after birth (birth to the first birthday) is labeled infancy, which is followed by childhood. Childhood is usually subdivided into two phases, early and middle. The former approximates the "preschool" years, about I through 5 years of age. The latter approximates the "elementary school" years, about 5-6 through 10-1। years. The upper limit of middle childhood is arbitrary because it is followed by adolescence, which is variable in when it starts. Some fourth grade girls, for example, who are about 9-10 years of age, have already entered the early stages of adolescence. The termination of adolescence is also quite variable so that it is also difficult to specify when adulthood begins. Biologically, some girls are sexually mature by 12 years of age and some boys are sexually mature by 14 years of age; i.e., they are biologically adult. Yet, they are adolescents in the eyes of society. Adulthood is a socially defined concept, usually in the context of completing high school, and in some instances, completing college.

This chapter has several objectives:

- What are the basic principles of growth, maturation, and development?

- How do they interact during childhood and adolescence?

- What is the pattern of age changes and sex differences in growth, maturation, and development from childhood through adolescence?

- What is the pattern of change in the performance motor, strength and aerobic tasks from childhood through adolescence? 


\section{GROWTH, MATURATION, AND DEVELOPMENT}

Children and adolescents experience three interacting processes: they grow, mature and develop (Table I). These terms are often treated as having the same meaning. They are, however, three distinct tasks in the daily lives of children and adolescents for approximately the first two decades of life.

\section{Growth}

Growth refers to the increase in the size of the body as a whole and of its parts. Thus, as children grow, they become taller and heavier, they increase in lean and fat tissues, their organs increase in size, and so on. Heart volume and mass, for example, follow a growth pattern like that for body weight, while the lungs and lung functions grow proportionally to height. Different parts of the body grow at different rates and different times. This results in changes in body proportions - relationship of one part of the body to another. The legs, for example, grow faster than the trunk during childhood; hence, the child becomes relatively longer-legged for his or her height.

Table I. Universal tasks of childhood and adolescence.

\begin{tabular}{lll}
\hline GROWTH: & MATURATION: & DEVELOPMENT: \\
Size & Skeletal & Cognitive \\
Proportions & Sexual & Emotional \\
Physique & Somatic & Social \\
Composition & Neuroendocrine & Motor \\
Systemic & Neuromuscular & Moral \\
& SELF-ESTEEM & \\
& BODY IMAGE & \\
& PERCEIVED COMPETENCE &
\end{tabular}

\section{Maturation}

Maturation refers to progress towards maturity or the biologically mature state. It is an operational concept because the mature state varies with body system. All tissues, organs, and systems of the body mature. Maturation is process which should be viewed in two contexts - timing and tempo. Timing refers to when specific maturational events occur, e.g., age at the beginning of breast development in girls, the age at the appearance of pubic hair in boys and girls, or the age at maximum growth during the adolescent growth spurt. Tempo refers to the rate at which maturation progresses, e.g., how quickly or 
slowly the youngster passes through the adolescent growth spurt. Timing and tempo vary considerably among individuals.

\section{Development}

Development refers to the acquisition of behavioral competence - the learning of appropriate behaviors expected by society. As children experience life at home, school, church, sports, recreation, and other community activities, they develop cognitively, socially, emotionally, morally, and so on. They are learning to behave in a culturally appropriate manner.

The three processes, growth, maturation and development, occur at the same time and interact. They interact to influence the child's self-concept, self-esteem, body image, and perceived competence. Teachers and coaches (note, coaching is teaching) should be aware of these interactions. A mismatch between the demands of a sport and those of normal growth and maturation may be a source of stress among young athletes. How a youngster is coping with his/her sexual maturation or adolescent growth spurt, for example, may influence his/her behaviors, including sport-related behaviors and performance.

\section{GROWTH IN BODY SIZE AND COMPOSITION}

Height and weight are the two body dimensions most commonly used to monitor the growth of children and adolescents. With age, children are expected to become taller and heavier. Size attained at a given age (status) and rate of growth (progress) are usually monitored relative to growth charts. These charts are a reference for comparison for monitoring the growth status (size attained) of individuals or samples of children and adolescents. Revised charts height, weight and the body mass index (BMI, see below) for American children from birth to 20 years of age were recently made available (Kuczmarski et al., 2000). These are based on a nationally representative samples of American children and adolescents, and replace the earlier charts which were used internationally (Hamill et al., 1979). The charts include several curves which indicate the distribution of heights and weights (percentiles) at a given age. For example, a child at the 25th percentile for height is taller than $25 \%$, and is shorter than $75 \%$ of the children of the same age and sex.

Height and weight increase gradually during childhood. By about 9-10 years in girls and $1 \mathrm{I}-12$ years in boys, the rate of growth in height begins to increase. This marks the beginning of the adolescent growth spurt, a period of rapid growth that is highly variable among individuals. The rate of growth increases until it reaches a peak, which is called peak height velocity (PHV) or 
maximum growth in height during the adolescent spurt. Then it gradually decreases and growth in height eventually stops. Girls, on average, start their growth spurts, reach PHV, and stop growing about two years earlier than boys. Nevertheless, when the growth spurt starts, when PHV is reached, and when growth stops are very variable among individuals. Most other body dimensions follow a growth pattern similar to that for height and weight.

The growth spurt in body weight begins slightly later than that of height. Body weight is a composite measure of many body tissues, but it is often viewed in terms of its lean (fat-free) and fat components. Thus, body weight = fat-free mass (FFM) + fat mass (FM). Major components of FFM are skeletal muscle and bone mineral. FFM has a growth pattern like that for body weight and experiences a clear adolescent spurt. FM increases more gradually during childhood and adolescence. General guidelines for expected changes in height, weight, and body composition are summarized in Table 2 .

Height and weight are frequently used in the form of the body mass index (BMI) - weight divided by height squared $\left(\mathrm{kg} / \mathrm{m}^{2}\right)$. After an increase in infancy, the BMI declines through early childhood. It reaches its lowest point at about 5-6 years of age, and then increases with age through childhood and adolescence, and into adulthood. Sex differences in the BMI are small during childhood, arise during adolescence, and persist into adulthood. The rise in the BMI after the low point at about 5-6 years of age has been labeled the "adiposity rebound". It is suggested that children who have an early "rebound" have an increased probability of being overweight in late adolescence and young adulthood. This hypothesis, however, needs further confirmation.

An elevated BMI is generally accepted as an indicator of adiposity or fatness in public health and nutritional surveys. An international reference for the definition of overweight and obesity during childhood and adolescence has been recently developed (Cole et al., 2000). These internatinally recommended age- and sex-specific cut-off points of the BMI for overweight and obesity between 2 and 18 years of age are based on pooled data from six nationally representative cross-sectional growth surveys - Brazil, Great Britain, Hong Kong, the Netherlands, Singapore, and the United States. In establishing the cut-off points, a BMI of $25.0 \mathrm{~kg} / \mathrm{m}^{2}$ at 18 years of age was considered overweight and a BMI of $30.0 \mathrm{~kg} / \mathrm{m}^{2}$ at 18 years of age was considered obese. Curves were then mathematically fit to the pooled BMI data from 2 years of age on so that they passed through a BMl of $25 \mathrm{~kg} / \mathrm{m}^{2}$ and $30 \mathrm{~kg} / \mathrm{m}^{2}$ at 18 years of age (retro-fitting). The values at each half year from 2 to 18 years of age are the respective cut-off points for overweight and obesity. 
The interpretation of the BMI in childhood, adolescence and young adulthood as an indicator of fatness needs care. An elevated BMI is not necessarily indicative of fatness during childhood and adolescence. The BMI is reasonably well correlated with total body fat and percentage fat in heterogeneous samples, but has limitations. Associations between BMI and fatness indicate a wide range of variability so that children with the same BMI can differ considerably in percentage fat and total fat mass, which emphasizes the need for care and sensitivity in the use and interpretation of the BMI as an indicator of fatness in individual children and adolescents.

Table 2. Guidelines for expected changes in height, weight, and body composition.

Pre-Adolescence or Pre-Puberty (about 6-10 years of age)

Children are expected to grow, i.e., increase in weight and height. Although there is much variation among individuals, children gain, on average, about 5-8 cm (2 to 3 inches) per year and about $2-3 \mathrm{~kg}$ (5 to 7 pounds) per year between 6 and 10 years of age. As adolescence and puberty begin, growth rates increase, first in height and then in weight.

\section{Adolescence and Puberty}

Adolescence is characterized by the growth spurt and sexual maturation. It is a time of considerable variation in when events occur and the rate at which children pass through them.

The following highlights general trends that characterize the growth spurt:

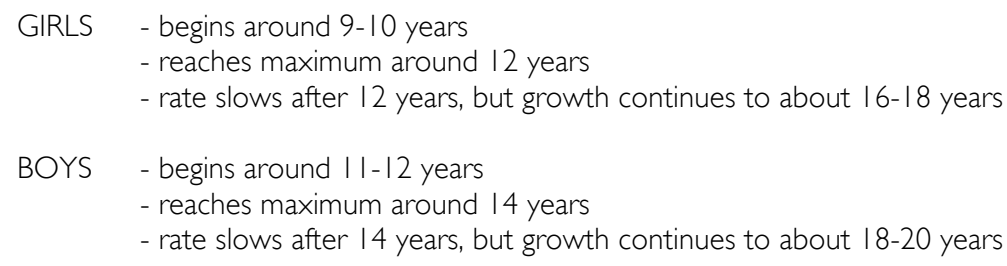

Growth in height continues into the early 20s in some girls and boys. There is considerable variation among individuals in TIMING (when the adolescent spurt occurs) and TEMPO (rate of progress through the spurt).

Body weight, FFM, and muscle mass also show adolescent spurts; they occur, on average, several months after the maximum rate of growth in height.

During the interval of maximum growth in height (about II- 13 years in girls and $13-15$ years in boys), girls gain about $7 \mathrm{~kg}$ ( 15 pounds) in FFM while boys gain double this value, $14 \mathrm{~kg}$ (31 pounds); girls gain a bit more FM than boys during the interval of the growth spurt, $3 \mathrm{~kg}(6$ pounds) versus $1.5 \mathrm{~kg}$ (3 pounds).

In a sense, during the growth spurt, "First you stretch them and then you fill them out!" Adapted from Malina et al. (2004). 


\section{BIOLOGICAL MATURATION}

The maturity status and progress of children and adolescents are ordinarily viewed two ways: skeletally and sexually. The timing of PHV is also an excellent maturity indicator, but longitudinal data are required to derive it. Maturation of the skeleton focuses on the bones of the hand and wrist, which generally reflect the remainder of the skeleton. An x-ray of the hand and wrist is needed to assess skeletal maturation. As such, the method has limited utility outside of a clinical setting. It is, however, a valuable method that is useful throughout childhood and adolescence, and is also used along with height at a given age to predict adult height.

Sexual maturation is based on the development of the breasts and pubic hair in girls and the testes and pubic hair in boys. Assessment of sexual maturation is ordinarily done at clinical examination by a physician. Age at menarche, the first menstrual period, is the most commonly used indicator of sexual maturity in girls.

The two most obvious features of biological maturation during adolescence are puberty or sexual maturation, and the growth spurt (see above). The first physically apparent sign of sexual maturation in girls is usually the initial development of the breasts, followed by the appearance of pubic hair. The first overt sign of sexual maturation in boys, on average, is the initial enlargment of the testes, followed by the appearance of pubic hair. Each of these secondary sex characteristics goes through a series of changes as the individual passes through puberty to maturity. They are usually assessed by a physician at a clinical examination. Their assessment requires invasion of the youngster's privacy at a time of life when he/she is learning to cope with the physiological changes that are occurring during puberty. Monitoring of these characteristics requires utmost care and sensitivity to the youngster involved. Guidelines for normal variation in sexual maturation are outlined in Table 3.

Age at menarche is limited to girls since male puberty has no corresponding physiological event. Menarcheal status (i.e., has menarche occurred or not occurred) and age at menarche in individual girls can be obtained with a careful and sensitive interview. The average age at menarche in American girls is 12.8 years, although normal variation ranges from 9 through 17 years of age.

It is important that teachers and coaches are aware of such variation among individuals as well as the significance of sexual maturation for growth and behavioral development. Sexual maturation in boys is accompanied with marked gains in muscle mass and strength, and broadening of the shoulders 
relative to the hips. In girls, it is accompanied by smaller gains in muscle mass and strength, by a widening of the hips relative to the shoulders, and by gains in fatness. The net result is sex differences in strength, body build, and body composition in late adolescence and young adulthood. Sexual maturation also influences behavioral development, for example, increased self-consciousness, concern with weight gain in girls, relationships with the opposite sex, and so on.

Table 3. Guidelines for normal variation in sexual maturation.

\section{GIRLS}

- The first physically apparent sign of sexual maturation in girls is the initial enlargement of the breasts. It occurs, on average, at about 10 years of age, but may occur before 9 years in about $10 \%$ of girls and not until after 12 years in another $10 \%$.

- Mature breast development occurs, on average, between 14 and 15 years of age. However, maturity may occur as early as 12 years in some girls and not until 16 or 17 years in others.

- $\quad$ Progress from initial to mature breast development is highly variable among girls. Some girls may pass through the process in 2 years, while others may take 5 or more years.

- Menarche, the first menstrual period, is a rather late maturational event of puberty. It ordinarily occurs after maximum growth in height (peak height velocity). The average age at menarche for American girls is 12.8 years.

\section{BOYS}

- Initial enlargement of the genitals (testes and penis) marks the first physically apparent sign of sexual maturation in boys. It occurs, on average, about I I years of age, but may occur around 9 years in about $10 \%$ of the boys and not until after 13 years in another $10 \%$ of the boys.

- Mature genital development occurs, on average, at about 15 years of age. However, maturity may occur as early as 13 years and after 18 years.

- $\quad$ Progress from initial to mature genital development is highly variable among boys. Some boys may pass through the process in 2 years, while others may take about 5 or more years.

Adapted from Malina et al. (2004).

\section{BEHAVIORAL DEVELOPMENT}

Development of behavioral competence proceeds simultaneously in several domains - cognitive, social, emotional, moral, and motor. Motor development, i.e., the acquisition of motor competence, and motor performance are considered in a separate section. 


\section{Middle Childhood}

The period between the preschool years and adolescence is often called middle childhood. It approximately spans entrance into school (first grade) to the onset of puberty (which, as indicated above, is variable in timing).

Competence gradually develops in many behavioral domains during middle childhood. However, two features are especially significant. First, the child gradually refines his/her self-concept: Who am I?, How do I feel about myself?, Where do I fit in?, and so on. Second, the child learns many skills, including cognitive skills - reading, writing, number manipulation and others, and interpersonal behaviors and relationships that underlie social, emotional and moral competence - sharing, cooperation, honesty, sensitivity to others, and so on. In the development of behavioral competence, the child often evaluates himself or herself. They very often ask questions about their identity and how others perceive them. Two primary sources of feedback in this selfevaluative process are adults, specifically parents, teachers and coaches, and peers (playmates and teammates). It is essential that adults who work with children be aware of their developing sense of self and the ongoing process of self-evaluation. Guidelines for the development of cognitive and social competence during middle childhood are summarized in Table 4.

Table $4 \mathrm{a}$. Guidelines for the development of cognitive and social competence during middle childhood (5-8 years).

\section{Cognitive Competence}

- Cognitive skills become elaborated as children show longer attention spans and increased problem solving ability.

- Children are able to handle multiple pieces of information; however, they have difficulty handling abstract or hypothetical questions.

- A major factor limiting the cognitive competence of young children is their lack of knowledge and experience using their developing skills.

\section{Social Competence}

- Children are expanding their understanding of self, i.e., self-concept formation.

- Children are interested in others, and often use other children as a reference of comparison in making self-evaluations and in defining themselves in terms of groups to which they belong.

- The peer group emerges as an important influence on children's behaviors. They are generally same-sex groups. Children have a strong sense of security in the group and in organized group activities.

- Given this sense of the group, children can learn a good deal from each other, which emphasizes the potential importance of cooperative learning environments. 
Table 4b. Guidelines for the development of cognitive and social competence during late childhood and early adolescence (9-12 years).

\section{$\underline{\text { Cognitive Competence }}$}

- Cognitive skills become more elaborated as children show longer attention spans and increased problem solving ability, and are able to handle multiple pieces of information.

- Logical thinking skills and hypothetico-deductive reasoning, and the ability to think about abstract concepts emerge during early adolescence.

\section{$\underline{\text { Social Competence }}$}

- The strength of the peer group increases. The group is focal and is a means of establishing independence from adults.

- Individual differences in the onset of the growth spurt and puberty influence relationships with others and definition of the social self.

- A major social developmental task that emerges at this time is the formation of personal identity, i.e., accepting the self as worthy and different from others.

- There is a gradual shift from identifying with same sex peers to learning roles in heterosexual situations.

Adapted from Sproufe et al. (1992).

It is during middle childhood that the peer group emerges as a source of support, criticism, and comparison in handling the many challenges associated with an emerging sense of behavioral competence. Peer group activities occur in many settings and children have multiple peer groups, both formal as in school, church and organized sport, and informal as in neighborhoods and playgrounds. The significance and strength of peer groups increase with age during middle childhood.

The organized sport setting is a major source of peer group experiences for many children. In highly individual sports such as gymnastics, swimming, diving, figure skating and wrestling, coaches need to be especially sensitive to the child's need for group affiliation and the need to develop a sense of the group. 
Table 5. Guidelines for the development of cognitive and social competence during adolescent years

\section{Cognitive Competence}

- Progress in logical thinking, hypothetico-deductive reasoning, and handling of abstract concepts continues.

- Enhanced abstract thinking is the basis for the ability for introspection. It is also the basis for emerging relationships between cognition and emotions.

- These cognitive skills expand the adolescent's ability to reason about moral and ethical issues.

\section{Social Competence}

- The formation of personal identity becomes crystallized, which contributes to establishing independence, i.e., the self as an independent person.

- The older adolescent's sense of self becomes more integrated, which contributes to better understanding of the uniqueness of each individual and to the ability to reconcile personal inconsistencies.

- Social relationships become more important. These contribute to self-evaluation and identify formation. Relationships with the opposite sex are especially important.

- There is increased acceptance of an adult role in different groups.

Adapted from Sproufe et al. (1992).

\section{Adolescence}

Adolescence, the transition from childhood to adulthood, is a period of major changes physically and behaviorally. The developmental tasks of adolescence are many, but three stand out. First, it is a period of physiological learning as the youngster copes with the physical and physiological changes associated with the growth spurt and sexual maturation. The youngster must learn to understand and accept the changes, to accept his/her body, and to adapt to masculine and feminine roles. A major concern of adolescents is their physical appearance. Second, it is a period of new relationships with age peers. During middle childhood, peer groups were largely same sex. During adolescence, youngsters develop relationships with age peers of both sexes, so that they have a major concern for social acceptance. And, third, it is a period of striving for independence. The youngsters strive for emotional independence from parents and other adults as they prepare for adult roles. Hence, it is a time of emotional peaks and valleys, of self-doubt, of changes in self-esteem, and of changing interests. Many youngsters experience a decline in selfesteem as they go through the developmental tasks of adolescence. It is no surprise that many youngsters drop out of sport between 12 and 14 years of age. The demands of normal adolescence may play a role in this decision. 
Guidelines for the development of cognitive and social competence during adolescence are outlined in Table 5.

Adolescence appears to be a drawn out process in some cultures, for example, the United States. It appears to be a time of confusion and insecurity for many youth as they strive for independence and adulthood.

\section{PERFORMANCE}

The development of proficiency in a variety of movement skills is a major developmental task of childhood and adolescence. Skillful performance, of course, is an important component of sports. During the preschool years and extending into middle childhood, children develop basic competence in fundamental movement patterns such as running, jumping, skipping, and so on. These movements are the foundation for other skills and sport-specific skills, and for physical activity in general.

Children commonly enter school or organized youth sports programs at 5 or 6 years of age, when many are still developing the basic movement patterns. One of the objectives of physical education and youth sports programs is to teach skills. Teachers and coaches of children entering school or a sport should have an understanding of the development of movement patterns and knowledge of how to provide an environment in which these patterns can be nurtured and improved. A primary responsibility of teachers and coaches is to guide the skill development process from basic patterns to skillful performance.

As basic movement patterns are refined through appropriate instruction and practice, performance quality improves and the basic patterns are integrated into more complex movement sequences and skills required for specific games and sports. The transition from basic movement patterns to more complex sports skills depends upon individual differences in neuromuscular maturation, earlier experiences and opportunity for movement, and the quality of instruction and practice. A proficiency barrier may exist for some children who do not have such opportunities for instruction and practice. A key person in this process is the teacher or coach, who should be able to meet the developmental needs of young children or sport participants though appropriate instructional sequences and guided practice opportunities. It is important for teachers and coaches to know how to observe the movements of a child. All too often, individuals tend to focus on the end product of a movement, e.g., whether the ball was struck or how far a ball was kicked. A teacher or coach should be able to analyze a movement to determine what are the important elements to observe. As a 
corrollary, the teacher or coach should have a sound knowledge of activities and experiences that will help the young athlete to progress in the development of a basic skill or a more specialized skill sequence. This way they will be able to know the process of what the child is doing rather than the result of what the child is doing. Knowing the process of performance is important to being able to provide corrective, positive instructional feedback to help improve performance.

The development of proficiency in basic movement patterns is accompanied by improved levels of performance which can usually be quantified. These are outcomes of the performance of tasks, e.g., the distance or height jumped (power), the distance and accuracy a ball is thrown (power and coordination), the time elapsed in completing a 30-yard dash (speed). Performances on such standardized tasks improve with age during childhood, and boys perform, on average, better than girls. There is considerable overlap between the sexes during early and middle childhood. With the onset of adolescence, the performances of boys show an acceleration whereas those of girls improve to about 13-15 years of age and then improve only slightly.

Tests of performance include anaerobic and aerobic components. Anaerobic power is the maximal ability to perform short-term (usually less than 30 seconds), high intensity bouts of exercise as in the vertical jump or a sprint. As such, anaerobic power follows a pattern of growth like that for sprints and jumps. Aerobic power is the maximal ability to uptake, deliver, and utilize oxygen to produce energy under aerobic conditions. It is an important determinant of endurance events. Absolute maximal aerobic power (expressed as liters of oxygen per minute) increases in boys and girls with age, and shows a clear adolescent spurt as do other performance tasks. When maximal aerobic power is adjusted for body weight, it shows little change with age in boys but declines with age in girls.

Performance during adolescence is influenced in part by individual differences in the timing of the adolescent growth spurt. Performances in a variety of tasks show well-defined adolescent spurts. Measures of strength tend show peak gains after the time of maximum growth in height (peak height velocity) in boys and girls. However, the magnitude of the growth spurt in strength is only about one-half of the maximum gain in boys. The same trend is apparent for power (vertical jump) in boys, but corresponding data are not available for girls. The trends for measures of strength and power are similar in timing to those for body mass and muscle mass, both of which experience their maximum growth after peak height velocity. Maximal aerobic power shows an adolescent spurt that occurs very close in time to that for height in boys and girls. When motor performances of girls are related to the time before and after menarche, there are no consistent trends. Menarche is 
a late maturational event during puberty, and major gains in growth and performance have already occurred.

The overall pattern of age- and sex-associated changes in a variety of performance tasks during childhood and adolescence is summarized in Table 6. The trends are based on group averages. Some girls, especially those active in sport, improve their performances through adolescence.

Table 6. Guidelines for the development of motor competence during childhood and adolescence.

\section{$5-8$ years}

- By these ages, the majority of children have developed the basic movement patterns. Note, however, that some children have not yet mastered the basic movement patterns at theses ages and would benefit from systematic instruction and practice under the supervision of qualified teachers/coaches.

- Performance in a variety of strength, speed, and power tasks improves more or less proportionally to gains in body size. Balance and coordination tasks also improve.

\section{9-12 years - transition into adolescence}

- Performances in motor (many are anaerobic), strength and endurance (aerobic) tasks, on average, improve with age.

- Individual differences in the timing and tempo of the growth spurt and sexual maturation exaggerate differences among children in performance. This is especially apparent among children of the same age who differ in maturity status.

\section{$13+$ years -adolescence}

- Performance in motor, strength, and aerobic tasks continues to improve, on average, in boys.

- On average, the performances of girls tend to reach a plateau at these ages or improve only slightly. In young female athletes who are systematically training for a sport, performances improve into late adolescence.

Adapted from Malina et al. (2004).

\section{OVERVIEW AND IMPLICATIONS FOR TEACHING AND COACHING}

For the sake of convenience, the preceding discussion arbitrarily partitioned childhood and adolescence into three periods that approximate childhood (58 years), the transition into puberty (9-13 years) and later adolescence (14-18 years). The first period represents the ages when the majority of children enter organized sports programs. The second period highlights the transition 
from childhood into adolescence which has major physical, physiological, and behavioral changes. It is also a period during which many youth drop out of sport programs, either by choice or by the more selective nature of many programs. The third period approximates the high school years, when sport programs are more selective and demanding.

It is important to note that the age ranges are arbitrary, especially between the second and third periods. These ages span the transition from childhood into adolescence, and the timing and tempo of the transition is variable within and among individuals. Thus, many of the cognitive and social developmental issues in the high school years are reworked in the context of those in the transitional period.

Variation within and between individuals in growth, maturation, and development is considerable. The marked changes in body composition are of specific concern, especially to adolescent girls and to many coaches. Motor performance may be influenced by an especially rapid growth spurt in both sexes. Relationships between peers may influence social behaviors and in turn relationships with coaches.

A teacher or coach should be able to apply these general concepts of growth, maturation and development to fit the needs of the young athletes in his/her program. Several suggestions for coaches in dealing with the physical, behavioral, and motor changes associated with the transition into and during the adolescent growth spurt and sexual maturation follow:

- Be aware of individual differences. As youth enter adolescence and during adolescence, they needs reassurance that they are "normal", i.e., not different from their peers. This need most often occurs in youngsters who are extremely early or extremely late in maturation. Above all, coaches should not make fun of them; peers often do, especially in locker rooms. The young adolescent is very sensitive to the growth and maturational changes that are occurring, and must learn to adjust to them. Adolescence is a period of physiological learning. The adolescent needs the support of understanding adults to transcend these changes with a positive view of self.

- Adolescents are very sensitive about their body weight and shape. Given changes that occur in body composition during later childhood and adolescence, teachers and coaches should avoid comments about body weight, especially in girls who in many cultures are being taught that "thin is in." Adolescent girls are very sensitive to weight changes associated with growth and maturation, and do not need to be reminded of them. 
- Coaches should be careful in using body size as cut-points in sports. This especially affects late maturing youngsters who need to be given the opportunity to participate and to keep working at improving skills, and who need to be reassured that they will eventually grow and mature.

- Coaches should pay attention to the child's eating behaviors and diet. A well-balanced diet is essential to support the needs of growth and maturation, in addition to those specific to physical activity and regular training for sport. Megavitamins are not a replacement for a well-balanced meal. Be aware of the use of antihistamines to suppress diet and of other ergogenic aids.

- Teachers and coaches should be aware of expected developmental changes and should also be aware of how developmental changes may influence performance. Some examples:

- Since growth in height occurs before growth in body mass and strength, there may be temporary periods during which a boy or girl may appear to "outgrow his/her strength". The youngster needs reassurance that his/her strength will eventually catch-up.

- There may be intervals during which a skill may temporarily decline compared to performances prior to the growth spurt, or there may be intervals during which skills may not improve as quickly. These may be associated with rapid changes in body proportions during the adolescent growth spurt, or changes in body composition associated with sexual maturation. The legs, for example, experience their grow spurt before the trunk does, which temporarily alters the position of the center of gravity.

- Changes in body composition and development of the hips, particularly in girls, also may influence performance. The adolescent girl needs to be nurtured through these changes in a positive manner with appropriate instruction and practice in movement and sportspecific skills.

\section{REFERENCES}

Beunen G, Malina RM (1988) Growth and physical performance relative to the timing of the adolescent spurt. Exercise and Sports Science Reviews 16:503-540.

Clapp JF, Little KD (1995) The interaction between regular exercise and selected aspects of women's health. American Journal of Obstetrics and Gynecology 173:2-9. 
Cole TJ, Bellizzi MC, Flegal KM, Dietz WH (2000) Establishing a standard definition for child overweight and obesity worldwide: International survey. British Medical Journal 320:1240-1243.

Hamill PV, Drizd TA, Johnson CL, Reed RB, Roche AF, Moore WM (1979) Physical growth: National Center for Health Statistics percentiles. American Journal of Clinical Nutrition 32:607-629.

Kuczmarski RJ, Ogden CL, Grummer-Strawn LM, Flegal KM, Guo SS, Wei R, Mei Z, Curtin LR, Roche AF, Johnson CL (2000): CDC growth charts: United States. Advance Data from Vital and Health Statistics, no 314. Hyattsville, MD: National Center for Health Statistics.

Levine MD (1983) Middle childhood. In MD Levine, WB Carey, AC Crocker, RT Gross (Eds). Developmental Pediatrics. Philadelphia: Saunders, pp I08-132.

Loucks AB, Vaitukaitis J, Cameron JL, Rogol AD, Skrinar G, Warren MP, Kendrick J, Limacher MC (1992) The reproductive system and exercise in women. Medicine and Science in Sports and Exercise 24:S288-293.

Malina RM (1994) Physical growth and biological maturation of young athletes. Exercise and Sport Sciences Reviews 22:389-433.

Malina RM (1996) The young athlete: Biological growth and maturation in a biocultural context. In FL Smoll, RE Smith (Eds). Children and Youth in Sport: A Biopsychosocial Perspective. Dubuque, IA: Brown and Benchmark, pp I6I-186.

Malina RM (1998) Growth and maturation of young athletes: Is training for sport a factor. In KM Chang, L Micheli (Eds): Sports and Children. Hong Kong: Williams and Wilkins, pp |33-161.

Malina RM, Beunen G (1996) Monitoring of growth and maturation. In $\bigcirc$ Bar-Or (Ed): The Child and Adolescent Athlete. Oxford: Blackwell Science, pp 647-672.

Malina RM, Bouchard C (199I) Growth, Maturation, and Physical Activity. Champaign, IL: Human Kinetics.

Malina RM, Bouchard C, Bar-Or O (2004) Growth, Maturation, and Physical Activity, 2nd edition. Champaign, IL: Human Kinetics.

Sroufe LA, Cooper RG, DeHart GB, Marshall ME (1992) Child Development: Its Nature and Course. New York: McGraw-Hill. 

Série

Investigação

Imprensa da Universidade de Coimbra

Coimbra University Press

2010

- U r

C • 